\title{
Coeval granitic magmatism in the southern segment of the Liupanshan at the SW margin of the NCC: Implications for Paleoproterozoic extension
}

\author{
Huan $\mathrm{Xu}^{1}$, Jin-Hai Luo ${ }^{1, *}$, Jia You ${ }^{2}$, Yi-Fei $\mathrm{Li}^{1}$, and Guan-Xu Chen ${ }^{1}$ \\ ${ }^{1}$ State Key Laboratory of Continental Dynamics, Department of Geology, Northwest University, Xi'an, China \\ ${ }^{2}$ The Second Oil Production Plant of Changqing Oilfield Company, Qingyang, China
}

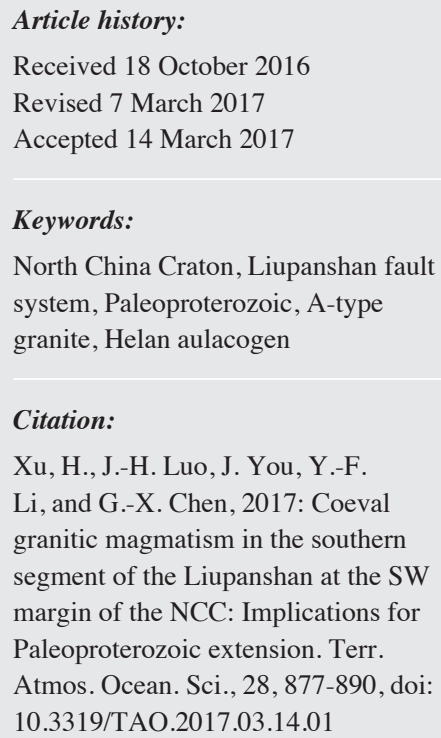

Xu, H., J.-H. Luo, J. You, Y.-F. Li, and G.-X. Chen, 2017: Coeval granitic magmatism in the southern segment of the Liupanshan at the SW margin of the NCC: Implications for Paleoproterozoic extension. Terr. Atmos. Ocean. Sci., 28, 877-890, doi: 10.3319/TAO.2017.03.14.01

\begin{abstract}
The ages of the Shizuizi, Baojiashan and Duanjiaxia granites are poorly constrained. They are exposed along the southern segment of the Liupanshan fault system at the southwestern margin of the North China Craton. They form a NW-trending belt of coeval A-type granitic magmatism, characterized by high $\mathrm{Si}$, alkalis, $\mathrm{Rb} / \mathrm{Sr}$, and $\mathrm{Ga} / \mathrm{Al}$. Their trace element characteristics include relative enrichments in $\mathrm{K}, \mathrm{Rb}$, and $\mathrm{Th}$, and depletions in $\mathrm{Ti}, \mathrm{Ta}, \mathrm{Nb}, \mathrm{P}$, and $\mathrm{Sr}$. Zircons from the granite yield $\mathrm{U}-\mathrm{Pb}$ age of $1738 \pm 15 \mathrm{Ma}$ for the Baojiashan granite which has similar zircon U-Pb ages with Shizuizi (1778 Ma) and Duanjiaxia (1802 Ma) granites. The granite has negative $\varepsilon_{\mathrm{Nd}}(\mathrm{t})$ of -22.5 to -20.0 and the two-stage model ages of $2.29-2.45 \mathrm{Ga}$. An analysis of the regional tectonics suggests that the granites were emplaced during Paleoproterozoic extension at the southwestern margin of North China Craton, where magmatism was caused by tectonic activity related to the development of the Helan aulacogen.
\end{abstract}

\section{INTRODUCTION}

The North China Craton (NCC) formed by processes of orogenesis, uplift, and extension during the late Paleoproterozoic and early Mesoproterozoic (Zhai and Santosh 2011, 2013; Zhai et al. 2014). It is composed of eastern and western blocks, separated from each other by the Central Orogenic Belt, which formed prior to $1.85 \mathrm{Ga}$ (Jiang et al. 2011; Liu et al. 2013). The western continent consists of the Yinshan and Ordos blocks (Zhao et al. 2005), which amalgamated at $\sim 1.95 \mathrm{Ga}$ (Li et al. 2013). After $1.8 \mathrm{Ga}$, mantle plume activity caused uplift and extension in the NCC, resulting in rifting and the development of the Helan, Xiong'er, and Yanshan-Taihang aulacogens (Fig. 1; Li et al. 2000; Zhao et al. 2007; Gao et al. 2013). Late Paleoproterozoic and Mesoproterozoic rifting was accompanied by extensive magmatism, including extrusion of the Xiong'er Group volcanics (1.80 - 1.75 Ga; Zhao et al. 2004; Xu et al. 2007) and intrusion of coeval granodiorites and porphyries

\footnotetext{
* Corresponding author

E-mail:luojh@nwu.edu.cn
}

(Zhao et al. 2007; Cui et al. 2010), mafic dike swarms of the Xiong'er aulacogen (Hou et al. 2010), and mafic dike swarms and alkaline intrusives of the Yanshan-Taihang aulacogen (1.77 - 1.78 Ga; Peng et al. 2004; Yang et al. 2007; Dong et al. 2010).

Direct petrological and geochronological associations in the Paleoproterozoic aulacogen in the southern segment of Helanshan and the Liupanshan Mountains are obscured by the overlying Meso-Cenozoic metasedimentary strata, and reactivation of the Liupanshan fault system, thereby limiting our understanding of the Paleoproterozoic and Mesoproterozoic tectonic framework in the area (Che et al.2011). The Helan aulacogen has been identified using seismic data at the western margin of the NCC, and sedimentology in the northern part of the Helanshan area. Seismic sections show a series of extensional faults in the Proterozoic successions, and that the thickness $(4000-5000 \mathrm{~m})$ and distribution of Mesoproterozoic strata were controlled by synsedimentary faulting (Wang 1995; Hua and Qiu 2001). Similar lithological and tectonic characteristics have been identified in the 


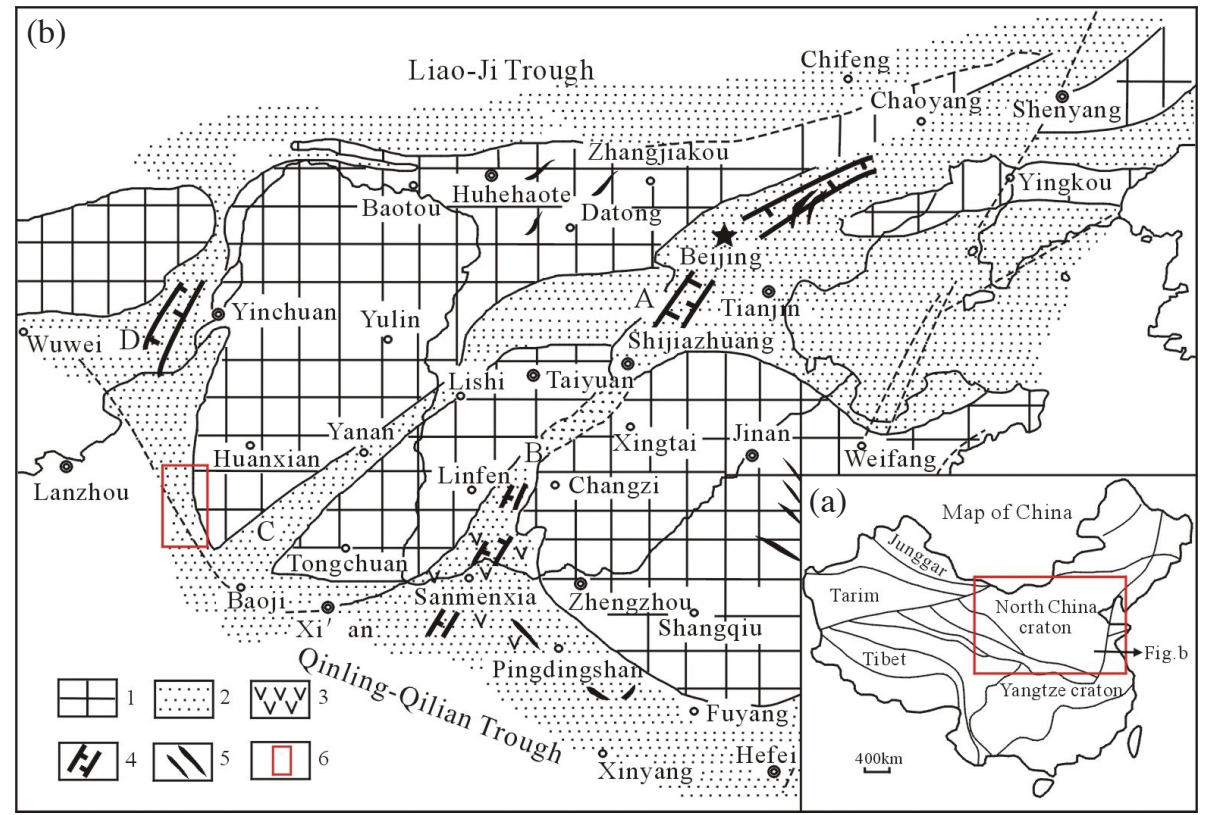

Fig. 1. (a) Regional geological map of China; (b) sketch tectonic map of the NCC in Meso-Neo proterozoic (after Che et al. 2011). (Color online only)

Note: 1: ancient lands; 2: seas; 3: intermediate-basic volcanic rocks; 4: rift axis; 5: Archean gneissosity; 6: study area; A: Yanshan-Taihang ancient rift; B: Xiong'er ancient rift; C: Jin-Shaan ancient rift; D: Helan ancient rift; E: Jartai ancient rift.

Yanliao aulacogen (Wang 1995; Hua and Qiu 2001; Gao et al. 2010). Previous studies yielded Paleoproterozoic and Mesoproterozoic ages for granitic magmatism in the Helan aulacogen (e.g., He et al. 2005; Wang et al. 2012; Gao et al. 2013); however, our understanding of the causes of magmatism, the tectonic setting, and the development of the Helan aulacogen remain unclear. In this paper, we present new geochronological and geochemical data for the Tiemahe and Duanjiaxia granites, propose a genetic model, constrain the tectonic setting for emplacement of the granites, and consider the implications of the results for the evolution of the southwestern margin of the NCC and the formation of the Helan aulacogen.

\section{REGIONAL GEOLOGY}

The Helan Aulacogen trends approximately north-south and occurs as a trench located between the Erdos block and Alxa block at the western margin of the NCC. During the Proterozoic, the Helan Aulacogen extended into the NCC and was filled with littoral clastic sediments and carbonates. The sediments are $\sim 1000 \mathrm{~m}$ thick, and were overlapped by the south Qilin Trough throughout the late Ordovician (Che et al. 2011). Geochronological studies on khondalite series rocks in the northern Helan Mountains have yielded metamorphic ages of $1.9-2.1 \mathrm{Ga}$ (Geng et al. 2010; Zhou et al. 2010; Xiao et al. 2011). The khondalite is the product of crustal maturity in the Paleoproterozoic. Intrusive rocks in the area yield a magmatic age of $1.85 \mathrm{Ga}$ (Geng et al. 2010).
Magmatic rocks are poorly exposed in the southern parts of the Helan Aulacogen.

A belt of granitic intrusions, including the Baojiashan, Shizuizi, and Duanjiaxia granites, occurs along the Liupanshan fault system at the southwestern margin of the NCC (Fig. 2). The country rocks of the granites outcropping in the study area are were emplaced into Upper Ordovician marine clastic limestones, and Lower Cretaceous, Eogene, and Quaternary fluvio-lacustrine sandstones and mudstone; however, these relationships are obscured by Quaternary cover. The contact relationships between granites and their country rocks have been used to determine the ages of the granites (e.g., Che and Wang 1985). Based on field observations, Che and Wang (1985) proposed that the Baojiashan and Duanjiaxia granites are Mesozoic or Cenozoic in age, and that they formed by Meso-Cenozoic tectonic activity along the Liupanshan fault system. However, the magmatic, chronology, and geochemistry evidence needed to validate this hypothesis are lacking.

\subsection{Baojiashan Granite}

The Baojiashan granite is exposed along the Tiemahe River (Fig. 2) with total width more than $1000 \mathrm{~m}$. The country rock comprises Lower Cretaceous red sandstones and claystones, and diabase porphyries. Based on contact relationships and correlations with adjacent lithologies, Che (1963) proposed that the Baojiashan granite was emplaced during the Cretaceous and Eogene, and that it formed as a 


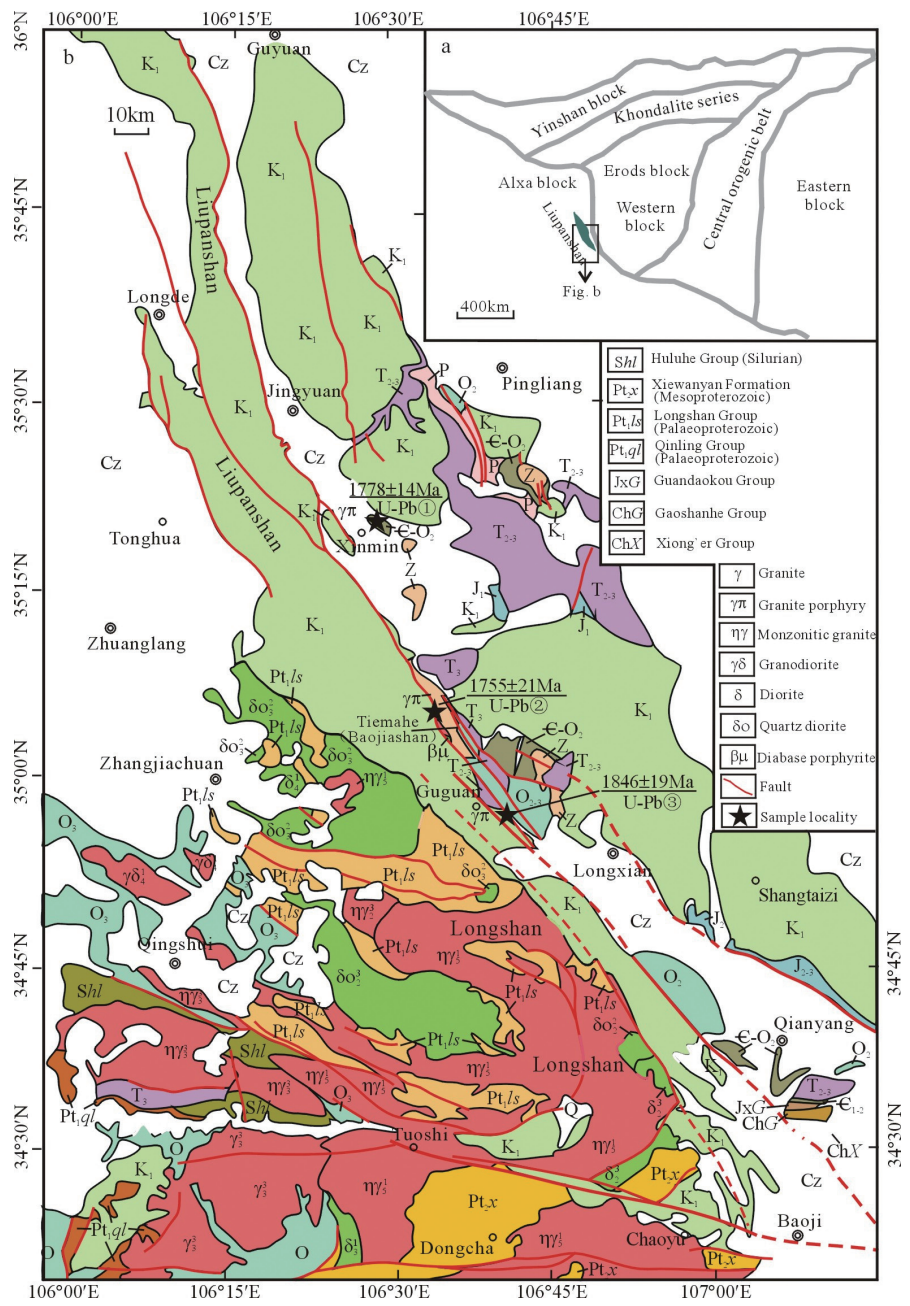

Fig. 2. Simplfied geological map of the studied area and its adjacent area in the southwestern margin of NNC.

Note: Cz: Cenozoic; $K_{1}$ : Lower Cretaceous; J: Jurassic; $T_{3}$ : Upper Triassic; $T_{2}$ : Middle Triassic; P: Permian; $S_{1}$ : Lower Silurian; $O_{3}$ : Upper Ordovician; $\mathrm{O}_{2}$ : Middle Ordovician; $\mathrm{O}_{1}:$ Lower Ordovician; $\in_{3}:$ Upper Cambrian; $\in_{2}:$ Middle Cambrian; Pt $t_{3}:$ Neoproterozoic; Pt $t_{2}:$ Mesoproterozoic; Pt $t_{1}:$ Paleoproterozoic; $\eta \gamma_{5}{ }^{1}$ : Triassic monzonitic granite; $\delta_{4}{ }^{l}$ : Devonian diorite; $\gamma \delta_{4}{ }^{l}$ : Devonian granodiorite; $\gamma_{3}{ }^{3}$ : Silurian granite; $\eta \gamma_{3}{ }^{3}$ : Silurian monzonitic granite; $\delta o_{3}{ }^{2}$ : Ordovician quartz diorite; $\eta \gamma_{2}{ }^{3}:$ Neoproterozoic monzonitic granite; $\delta_{2}{ }^{3}:$ Neoproterozoic diorite; $\delta o_{2}{ }^{3}:$ Neoproterozoic quartz diorite; $\delta o_{2}{ }^{2}$ : Mesoproterozoic quartz diorite; (1) Shizuizi granite (Wang et al. 2012); (2) Baojiashan granite; (3) Duanjiaxia granite (You et al. 2014).

result of Liupanshan faulting during the Meso-Cenozoic. This age was later refined by Che and Wang (1985), who suggested that the pluton is Cenozoic in age based on its relationship with surrounding rocks. Zircon U-Pb geochronology yielded an age of 1365 Ma for the Baojiashan granite, leading Yan (1985) to conclude that the granite formed in the Mesoproterozoic. Attempts to determine the age of the associated diabase porphyries have been unsuccessful.

\subsection{Shizuizi Granite}

The Shizuizi granite is poorly exposed, and was first mapped by the Geological Survey of Ningxia Province in 1997 - 2000 (Wang et al. 2012). It is located in Shizuizi Village, Xinmin, Jingyuan County, Ningxia Province (Fig. 2). The granite is surrounded by Eogene sandstones and Quaternary loess, and has been affected by extensive surface weathering (Gao et al. 2013). It is red in color, with porphyritic textures defined by $1-15 \mathrm{~mm}$ quartz, K-feldspar, and plagioclase phenocrysts. Quartz shows corrosion and has a modal abundance of $10 \%$. K-feldspar grains (modal abundance $=8 \%$ ) are tabular or columnar, and have been altered to kaolinite and sericite. The plagioclase content is low $(5 \%)$. The granite matrix is microcrystalline, consisting predominantly of feldspar and quartz, and it has been partially altered. The geochemistry of the granite is characterized by high $\mathrm{Si}$ and alkalis, with mean $\mathrm{Na}_{2} \mathrm{O}+\mathrm{K}_{2} \mathrm{O}$ $=7.6$ wt. $\%, \mathrm{~K}_{2} \mathrm{O} / \mathrm{Na}_{2} \mathrm{O}=2.2-7.4$, and $\mathrm{A} / \mathrm{CNK}=0.9-1.1$ (mean $\mathrm{A} / \mathrm{CNK}=1.0$ ); thus, the Shizuizi granite is subalkaline metaluminous to weakly peraluminous. Total REE ( $\Sigma$ REE) contents are high, ranging from $340-470 \mathrm{ppm}$. The granite shows a relative enrichment in LREE, and negative Eu anomalies. Trace element geochemistry is characterized by a relative depletion in high field strength elements, Ta, 
$\mathrm{Nb}$, and $\mathrm{Ti}$, and enrichment in $\mathrm{Rb}, \mathrm{Ba}$, and $\mathrm{Th}$, characteristic of post-orogenic A-type granite (Gao et al. 2013).

Although the Shizuizi granite has been mapped as a Late Triassic-Early Jurassic intrusion by the Ningxia geology survey institute, Gao (2001) suggested that both the Shizuizi granite and the intermediate-acidic Nanhuashan and Yueliangshan plutons in the northern Qilian Orogenic Belt are Paleoproterozoic in age. Wang et al. (2012) obtained a SHRIMP U-Pb zircon age of $1778 \pm 14 \mathrm{Ma}$ for the granite. Gao et al. (2013) discussed the A-type geochemical characteristics of the Shizuizi granite.

\subsection{Duanjiaxia Granite}

The Duanjiaxia granite is located in the northwestern Duanjiaxia Reservoir, Longxian County, Shaanxi Province, and is exposed at a number of small outcrops (Fig. 2). It comprises a series of granitic veins that have intruded Upper Ordovician marine clastic limestones; the contact relationship between the granite and surrounding rocks is unclear. The granite is dark red, with a porphyritic texture. Phenocrysts are K-feldspar $(\sim 20 \%)$, quartz $(\sim 15 \%)$, and plagioclase $(<5 \%)$. The $\mathrm{K}$-feldspar is euhedral-subhedral and tabular, measuring $0.5-3 \mathrm{~mm}$ in length. Some K-feldspar surfaces have been altered to sericite. Quartz phenocrysts are unaltered and show corrosion textures, while plagioclase grains are euhedral-subhedral and tabular in shape, showing twinning and weak alteration. The matrix of the granite is microcrystalline and is composed of feldspar and quartz. The granite porphyry contains high $\mathrm{SiO}_{2}$ (71.1 - 73.3 wt.\%) and is alkali-rich $\left(\mathrm{Na}_{2} \mathrm{O}+\mathrm{K}_{2} \mathrm{O}=7.6-8.7\right.$ wt.\%), with high $\mathrm{K}\left(\mathrm{K}_{2} \mathrm{O} / \mathrm{Na}_{2} \mathrm{O}=1.2-2.5\right.$, mean $\left.\mathrm{K}_{2} \mathrm{O} / \mathrm{Na}_{2} \mathrm{O}=2.0\right)$, making it metaluminous to weakly peraluminous $(\mathrm{A} / \mathrm{CNK}=0.9$ 1.1). It shows a relative enrichment in LREE and negative $\mathrm{Eu}$ anomalies. High field strength elements $(\mathrm{Ta}, \mathrm{Nb}$, and $\mathrm{Ti}$ ) are relatively depleted, while $\mathrm{K}, \mathrm{Rb}, \mathrm{Ba}$, and Th are enriched in the granite, characteristic of A-type granites derived from the partial melting of crust (You et al. 2014).

The Duanjiaxia granite has been mapped as dykes in a 1:50000 scale geological map of Guguan Town (1996), the 1:250000 geological map of Baoji City, and regional geological survey reports (2003). Based on contact relationships between the granite and country rocks, Che and Wang (1985) suggested that the Duanjiaxia granite is Late Cretaceous to early Paleogene in age; however, we obtained a weighted mean ${ }^{207} \mathrm{~Pb} /{ }^{206} \mathrm{~Pb}$ age of $1802 \pm 10 \mathrm{Ma}$ for the Duanjiaxia granite, indicating that it was emplaced during the Paleoproterozoic.

\section{PETROGRAPHY OF THE BAOJIASHAN GRANITE PORPHYRY}

Samples of Baojiashan granite porphyry were collected from the Tiemahe section in Longxian County, Shaanxi
Province (N35³'35.4”, E106³4'38.6”; Fig. 2). Exposure of the granite is obscured by Quaternary cover, and the largest outcrop is $>1000 \mathrm{~m}$ wide. The country rocks comprise Lower Cretaceous purple sandstones and mudstones, and Neoproterozoic (Sinian) gray limestones. Direct contacts between the granite porphyry and the country rocks could not be identified; consequently, it is not possible to speculate on the age of the granite through field observations.

The granite samples are red in color, with a porphyritic texture (Figs. 3a - b). Phenocrysts are composed predominantly of K-feldspar, and comprise $20 \%$ of the whole rock. The feldspar is altered and locally contains simple cassette twins and polysynthetic twins. Quartz phenocrysts comprise $8 \%$ of the rock, are unaltered, and have corroded edges. Plagioclase shows polysynthetic twinning and is weakly altered, comprising $5 \%$ of the whole rock. The matrix of the granite is aphanitic or microcrystalline, consisting of feldspar and quartz (Figs. 3c - d).

\section{ANALYTICAL METHODS}

\subsection{Zircon Separation and In Situ U-Pb Analysis}

Zircons were separated using heavy liquid and magnetic separation techniques, and handpicking under a binocular microscope. They were then mounted in epoxy resin and polished until their centers were exposed. Cathodoluminescence (CL) imaging was used to map the internal structure of zircon grains, employing a Quanta 400FEG environmental scanning electron microscope equipped with an Oxford energy dispersive spectroscopy system, and a Gatan CL3+ detector.

The U-Pb analyses of zircons were conducted on an Agilent 7500a ICP-MS equipped with a $193 \mathrm{~nm}$ ArF-excimer laser, and a homogenizing, imaging optical system. A fixed spot size of $30 \mu \mathrm{m}$ and a laser repetition rate of $6 \mathrm{~Hz}$ were employed throughout this study. Helium was used as the carrier gas to provide efficient aerosol delivery to the torch. The standard silicate glass, NIST 610, was used to calibrate the instrument $\left({ }^{238} \mathrm{U}\right.$ signal intensity $\left.>460 \mathrm{cps} \mu \mathrm{g}^{-1} \mathrm{~g}^{-1}\right)$ and ensure low oxide production (ThO/Th $<1 \%)$. The U/Th ion-signal intensity ratio was measured to monitor whether zircon vaporization was complete (Günther and Hattendorf 2005). Measurements were conducted using time-resolved analysis operating in fast peak jumping mode $(20 \mathrm{~ms}$ peak $^{-1}$ ) and DUAL detector mode using a short integration time. ${ }^{207} \mathrm{~Pb} /{ }^{206} \mathrm{~Pb},{ }^{206} \mathrm{~Pb} /{ }^{238} \mathrm{U},{ }^{207} \mathrm{~Pb} /{ }^{235} \mathrm{U}$, and ${ }^{208} \mathrm{~Pb} /{ }^{232} \mathrm{Th}$ were calculated using GLITTER 4.0 (Macquarie University), and then corrected using the Harvard zircon 91500 as an external standard, with a recommended ${ }^{206} \mathrm{~Pb} /{ }^{238} \mathrm{U}$ age of 1065.4 $\pm 0.6 \mathrm{Ma}$ (Wiedenbeck et al. 2004), to correct for instrument mass bias and depth-dependent elemental and isotopic fractionation. Concordia diagrams and weighted mean calculations were made using Isoplot software (ver. 2.49; Ludwig 2001). U, Th, and $\mathrm{Pb}$ concentrations were calibrated 

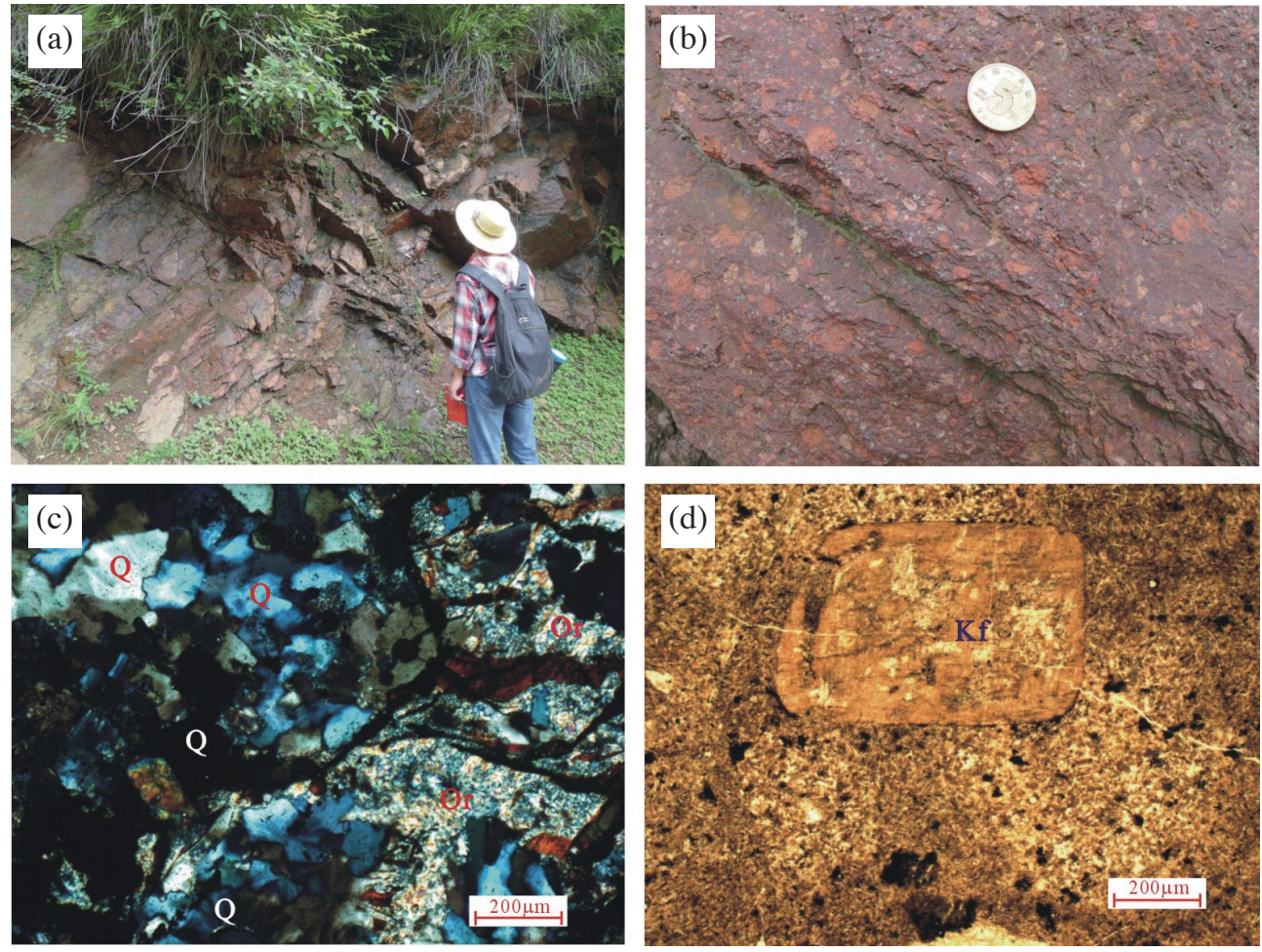

Fig. 3. (a) (b) Field photos of the Baojiashan granite; (c) cross-polarized light; (d) plane-polarized light of Baojiashan granite. Note: Kf: potash feldspar; Or: orthoclase; Q: quartz.

using ${ }^{29} \mathrm{Si}$ as an internal standard, and NIST SRM610 as an external standard. Zircon standards 91500 and GJ-1 were analyzed as unknowns. The two standard zircons yielded weighted mean ${ }^{206} \mathrm{~Pb} /{ }^{238} \mathrm{U}$ ages of $1064.4 \pm 3.1 \mathrm{Ma}(\mathrm{n}=16$, $2 \sigma)$ and $603.1 \pm 3.2 \mathrm{Ma}(\mathrm{n}=14,2 \sigma)$, respectively, which are in good agreement with the recommended ID-TIMS ages reported by Wiedenbeck et al. (1995).

\subsection{Major and Trace Element Analyses of Whole Rock}

Altered surfaces were removed from selected samples prior to their preparation. Samples were then washed and dried, and crushed to 60 mesh in an aluminum jaw crusher. Approximately $60 \mathrm{~g}$ of the crushed sample was milled in a WC Mill (T1-100, CMT) to < 200 mesh $(75 \mu \mathrm{m})$ for wholerock analysis.

Major elements oxides were determined by XRF (Rigaku RIX 2100) using Li-borate glass disks. Analysis of international rock standards (USGS) BHVO-1 and AGV-1 indicates that the analytical precision and accuracy are better than $5 \%$. Trace and rare earth elements were measured using an Agilent 7500a ICP-MS. Trace elements were analyzed using $50 \mathrm{mg}$ samples that were dissolved in a sealed, high-temperature and high-pressure bomb using equal parts of ultra-pure $\mathrm{HF}$ and $\mathrm{HNO}_{3}$. Analysis of USGS rock standards BHVO- 1 and AGV-1 indicates that the analytical precision is better than $5 \%$.

\subsection{Sm-Nd Isotope Analyses of Whole Rock}

Whole rock Sm-Nd isotope ratios were determined using a Micromass MC-ICP-MS Nu Plasma HR. Separation of $\mathrm{Sm}$ and $\mathrm{Nd}$ was done by using a routine two-columnion ion-exchange technique. Isotopic ratios were measured on Isoprobe mass spectrometer in a static mode. During our analyses, ${ }^{143} \mathrm{Nd} /{ }^{144} \mathrm{Nd}$ ratios of $0.512120 \pm 12(2 \sigma)$ were obtained for the international standard Shin Etou JNdi-1. Correction of isotopic mass fractionation for $\mathrm{Nd}$ was made with ${ }^{146} \mathrm{Nd} /{ }^{144} \mathrm{Nd}=0.7219$ (Wei et al. 2002; Liang et al. 2003).

\section{ANALYTICAL RESULTS}

\subsection{Zircon U-Pb Geochronology}

$\mathrm{U}-\mathrm{Pb}$ dating of zircons were performed at the State Key Laboratory of Continental Dynamics, Northwest University, $\mathrm{Xi}$ 'an, China. The CL images of representative zircons are shown in Fig. 4 and U-Pb data are listed in Table 1. Zircons from the Baojiashan granite porphyry are median size, euhedral-subhedral, and columnar, showing oscillatory zoning (Fig. 4). They contain high U (17.23 - $102.3 \mathrm{ppm})$ and Th $(10.90-92.19 \mathrm{ppm})$, with $\mathrm{Th} / \mathrm{U}=0.60-0.96$, indicating a magmatic origin. Forty zircon grains from the granite porphyry (sample LX03) were analyzed for U-Pb-isotopes. Twenty-nine analyses yielded concordant or near-concordant ages. From the age spectum diagram (Fig. 5a), a main 


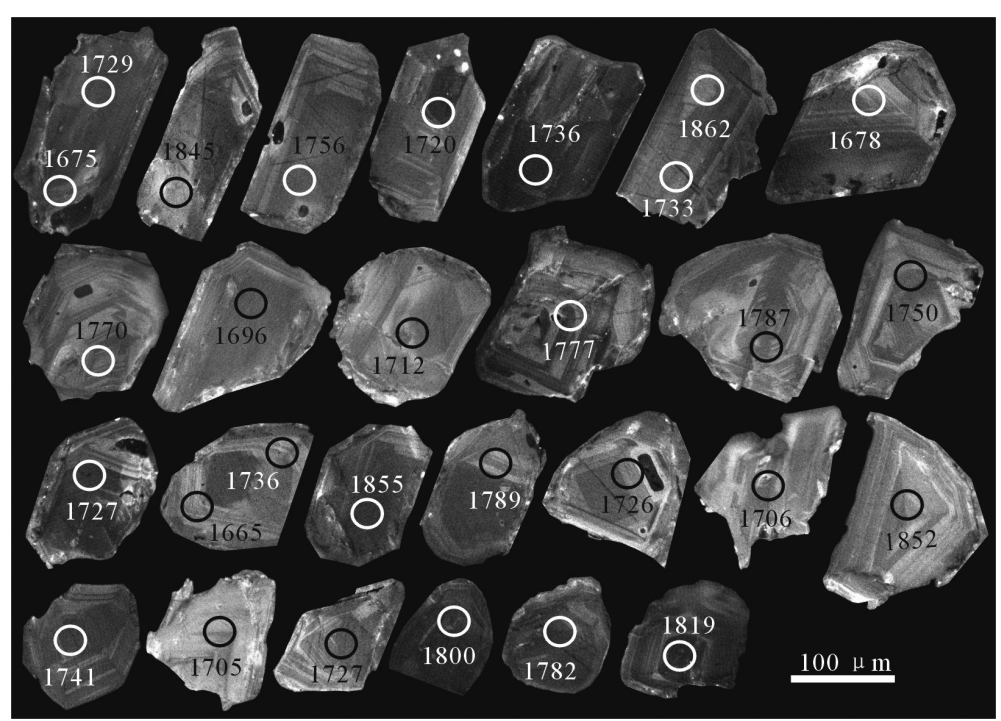

Fig. 4. Cathodoluminescence (CL) images of zircons from the granite in Baojiashan section.

Table 1. LA-ICP MS U-Pb data for zircons from the Baojiashan granite.

\begin{tabular}{|c|c|c|c|c|c|c|c|c|c|c|c|c|c|c|c|c|}
\hline \multirow{3}{*}{$\begin{array}{c}\text { Spot } \\
\text { No. }\end{array}$} & \multirow{3}{*}{$\begin{array}{c}\mathbf{P b}^{*} \\
(\mathbf{p p m})\end{array}$} & \multirow{3}{*}{$\begin{array}{l}{ }^{232} \mathbf{T h} \\
\text { (ppm) }\end{array}$} & \multirow{3}{*}{$\begin{array}{c}{ }^{238} \mathbf{U} \\
(\mathbf{p p m})\end{array}$} & \multirow{3}{*}{$T h / U$} & \multicolumn{6}{|c|}{ Istopic ratios } & \multicolumn{6}{|c|}{ Ages(Ma) } \\
\hline & & & & & \multicolumn{2}{|c|}{${ }^{207} \mathrm{~Pb} /{ }^{206} \mathrm{~Pb}$} & \multicolumn{2}{|c|}{${ }^{207} \mathrm{~Pb} /{ }^{235} \mathrm{U}$} & \multicolumn{2}{|c|}{${ }^{2066} \mathrm{~Pb} /{ }^{238} \mathrm{U}$} & \multicolumn{2}{|c|}{${ }^{207} \mathrm{~Pb} /{ }^{206} \mathrm{~Pb}$} & \multicolumn{2}{|c|}{${ }^{207} \mathbf{P b} /{ }^{235} \mathbf{U}$} & \multicolumn{2}{|c|}{${ }^{206} \mathrm{~Pb} /{ }^{238} \mathrm{U}$} \\
\hline & & & & & ratios & $1 \sigma$ & ratios & $1 \sigma$ & ratios & $1 \sigma$ & ages & 10 & ages & $1 \sigma$ & ages & $1 \sigma$ \\
\hline 2 & 30 & 37.61 & 01 & 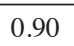 & & & & & & & 1741 & 37 & 741 & & 1747 & 21 \\
\hline 3 & 7.79 & 108 & 54 & 60 & 10445 & & & & 1976 & .00461 & 1705 & 41 & 747 & & 789 & 23 \\
\hline 6 & 11.96 & 23.2 & 28.08 & 83 & 1045 & .00224 & 4.59359 & .07408 & 31988 & 0.00454 & 1706 & 39 & 1748 & 13 & 789 & 22 \\
\hline 7 & 9.11 & 14.38 & 21.80 & 0.66 & 0.10278 & 0023 & 4.46547 & .07733 & 31616 & & 1675 & 41 & 1725 & 4 & 1771 & 22 \\
\hline 8 & & & 3 & & & & & & & & 1729 & 37 & & 3 & 06 & 22 \\
\hline 9 & & .90 & 17.23 & & 0822 & & & & 73 & & 1770 & 40 & 1788 & & 1808 & 23 \\
\hline 11 & .75 & 17.96 & 24.2 & & & & & & & & 1787 & 38 & 1789 & 13 & 1795 & 22 \\
\hline 12 & .99 & 34.72 & 46.56 & & & & & & & & 1695 & 37 & 1741 & 12 & 1784 & 22 \\
\hline 13 & & 31.74 & 35.21 & & & & & & & & 1712 & 38 & 1755 & 13 & 1795 & 22 \\
\hline 14 & & 20.58 & 7.31 & & & & & & & & 1726 & 38 & 1779 & & 1829 & 23 \\
\hline 15 & & 19.06 & 27.29 & & & & & & & & 1789 & 38 & 1794 & & 1802 & 22 \\
\hline 16 & & 16.91 & & & & & & & & & 1852 & 38 & 1794 & & 1748 & 22 \\
\hline 17 & & & & & & & & & & & & 37 & & & & 22 \\
\hline 19 & & & & & & & & & & & & & & & & 2 \\
\hline 20 & & 16.49 & 25.11 & 0.66 & & & & & & & 1678 & 40 & 1737 & & 1789 & 22 \\
\hline 21 & & 21.73 & 31.6 & 0.69 & 0.10222 & & 4.51278 & & 0.32073 & & 1665 & 38 & 1733 & 13 & 1793 & 22 \\
\hline 22 & 16.78 & 33.07 & 39.01 & & & & & & & & 1736 & 37 & 1753 & 12 & 1770 & 22 \\
\hline 24 & 14.46 & 27.67 & 31.81 & & & & & & & & 1845 & 37 & 1823 & 13 & 1807 & 22 \\
\hline 26 & 16.32 & 28.00 & 39.53 & 0.71 & & & & & & & 1727 & 37 & 1746 & 13 & 1764 & 22 \\
\hline 28 & 21.51 & 41.01 & 47.07 & 0.87 & 10745 & 16 & 5382 & & 32119 & 51 & 1757 & 36 & 1777 & 12 & 1796 & 22 \\
\hline 30 & 45.54 & 92.19 & 102.3 & 0.90 & 0.10535 & 0.00209 & 4.64272 & 0.06523 & 0.31986 & 0.00447 & 1720 & 36 & 1757 & 12 & 1789 & 22 \\
\hline 31 & 13.91 & 25.24 & 30.37 & 0.83 & 0.10867 & 0.00225 & 4.9129 & 0.07444 & 0.32801 & 0.00466 & 1777 & 37 & 1805 & 13 & 1829 & 23 \\
\hline 32 & & & & & & & & & & & 800 & 37 & & 13 & 1813 & 22 \\
\hline 33 & & & & & & & & & & & 1750 & 38 & 1773 & & 1793 & 22 \\
\hline 35 & & 25.32 & & & & & & & & & 1782 & 37 & 1776 & 13 & 1772 & 22 \\
\hline 36 & & 32.36 & 38.27 & & & & & & & & 1819 & 37 & 1792 & 13 & 1770 & 22 \\
\hline 37 & & 78.08 & 89.86 & & 0.10624 & & & & & & 1736 & 36 & 1766 & 12 & 1790 & 22 \\
\hline 39 & & 16.54 & 27.81 & & & & & & & & 1862 & 37 & 1818 & 13 & 1778 & 22 \\
\hline 40 & 17.25 & 32.17 & 39.41 & 0.82 & 0.10613 & 0.00218 & 4.65662 & 0.0698 & 0.318 & 0.00452 & 1734 & 37 & 1701 & 13 & 1780 & 22 \\
\hline
\end{tabular}

Note: $P b^{*}$ represents radiogenic lead in the table. 
(a)

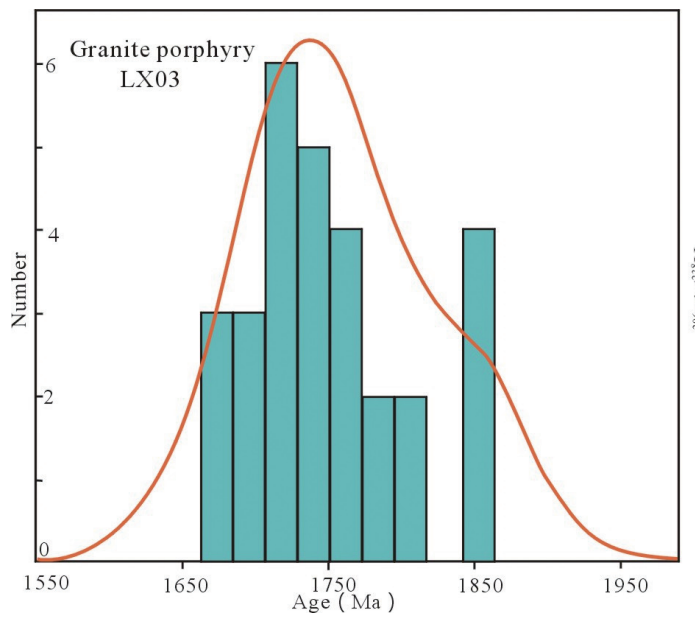

(b)

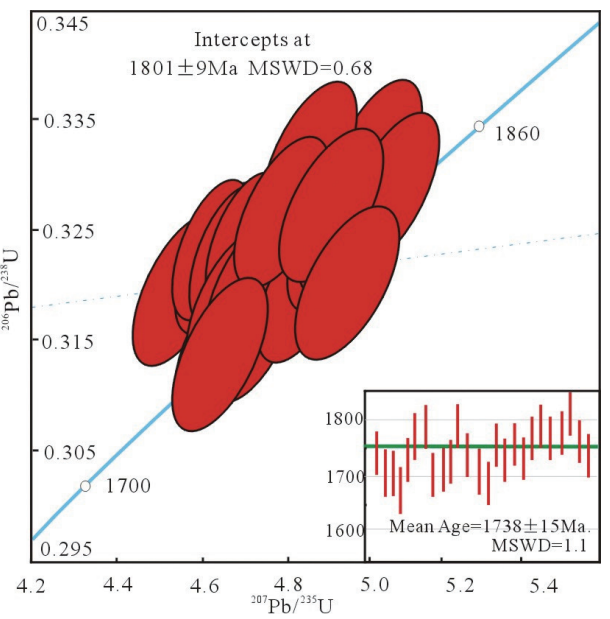

Fig. 5. (a) Zircon age spectum diagram; (b) Zircon U-Pb concordia and frequency bars diagram for Baojiashan granite. (Color online only)

age cluster (about $1740 \mathrm{Ma}$ ) and a minor age cluster (about $1850 \mathrm{Ma}$ ) can be found. We interpret the older ages as inherited ages and the younger age cluster is the activity age of the magmation. Because the ages are more concentrated (Fig. 5b), the intercept age [1801 $\pm 9 \mathrm{Ma}(\mathrm{MSWD}=0.68)]$ is lower intercept age and the upper intercept age is not available. Deleted four older ages, the weighted mean ${ }^{207} \mathrm{~Pb} /{ }^{206} \mathrm{~Pb}$ age of $1738 \pm 15 \mathrm{Ma}$ (MSWD = 1.1; Fig. 5). The Concordia diagram shows all the analyses are coeval and do not have inherited ages. Thus, the crystallization age of the granite porphyry may be $1738 \mathrm{Ma}$.

\subsection{Major Element Characteristics of the Baojiashan Granite}

Major and trace element analyses were performed at the State Key Laboratory of Continental Dynamics, Northwest University, Xi' an, China. Analytical results are listed in Table 2.

The major element geochemistry of the Baojiashan granite is characterized by high $\mathrm{Si}$ and alkalis. $\mathrm{The}^{\mathrm{SiO}} \mathrm{O}_{2}$ content ranges from $70.8-72.9$ wt. $\%$, and $\mathrm{K}_{2} \mathrm{O}=5.0-6.7$ wt. $\%$. Total alkalis $\left(\mathrm{K}_{2} \mathrm{O}+\mathrm{Na}_{2} \mathrm{O}\right)$ range from $7.9-8.9$ wt.\%, with $\mathrm{K}_{2} \mathrm{O} / \mathrm{Na}_{2} \mathrm{O}=1.7$ - 3.4. The rocks are classified as ferroan granites (Fig. 6), and their Rittman index $(\delta)$ values range from 2.1 - 2.8. $\mathrm{Al}_{2} \mathrm{O}_{3}$ values $(11.7-12.7 \mathrm{wt} . \%)$ are intermediate, and $\mathrm{A} / \mathrm{CNK}=0.9-1.2$, indicating that the granites are weakly peraluminous. In addition, low $\mathrm{CaO}(0.2-2.0$ wt.\%) and $\mathrm{MgO}(0.8-0.1$ wt.\%) are the characteristic of Baojiashan granite.

\subsection{Trace Element Characteristics of the Baojiashan Granite}

The Baojiashan granite contains high RREE (188.2
- $1133.4 \mathrm{ppm}$ ), with mean REE $=510.8 \mathrm{ppm}$, higher than the REE values of I-type $(\Sigma \mathrm{REE}=114.7 \mathrm{ppm})$ and S-type granites $(\Sigma \mathrm{REE}=173.1 \mathrm{ppm}$; Wu et al. 2007). Chondritenormalized REE patterns (Fig. 7) for the granite porphyry show a slight right dip. The granites show a negative Eu anomaly $(\delta E u=0.5)$ and LREE/HREE $=4.1-12.5$, indicating a strong relative enrichment in LREE (Table 2). In addition, $(\mathrm{La} / \mathrm{Sm})_{\mathrm{N}}=3.5-6.4$, indicating strong fractionation in LREE, whereas $(\mathrm{Gd} / \mathrm{Yb})_{\mathrm{N}}=1.1-3.3$, indicating weak fractionation in HREE (Fig. 4).

Trends in trace element abundances (Fig. 8) show that the Baojiashan granite is relatively depleted in high field strength elements (HFSEs; e.g., Nb, Ta, Ti, and Hf), and P and Sr. Large ion lithophile elements (LILEs; e.g., K, Rb, $\mathrm{Ba}$, and $\mathrm{Th}$ ) are relatively enriched.

\subsection{Sm-Nd Isotopic Composition of the Baojiashan Granite}

After the analysis of major and trace element, two samples (12LX11, 12LX12) were analyzed for Sm-Nd isotopes (Table 3). Initial ${ }^{143} \mathrm{Nd} /{ }^{144} \mathrm{Nd}$ ratios are expressed as $\varepsilon_{\mathrm{Nd}}(t)$ values where $t$ is the age of magma crystallization. The calculated $\mathrm{Nd}$ model ages are denoted as $\mathrm{T}_{\mathrm{DM} 1}$ relative to a depleted mantle source for single-stage evolution and as $\mathrm{T}_{\mathrm{DM} 2}$ relative to the average continental crust for two-stage evolution (Jahn and Condie 1995). The Baojiashan granite has negative $\varepsilon_{\mathrm{Nd}}(\mathrm{t})$ of -22.5 to -20.0 and the two-stage model ages of $2.29-2.45 \mathrm{Ga}$.

\section{DISCUSSION}

\subsection{Prtrogenesis of the Granites}

The Baojiashan granite, Duanjiaxia granite, and Shizuizi granite are distributed and exposed linearly along the 
$\mathrm{Xu}$ et al.

Table 2. Whole rock major-element (\%) and trace-element (ppm) compositions of Baojiashan granite.

\begin{tabular}{|c|c|c|c|c|c|c|c|c|c|}
\hline sample & 12LX06 & 12LX07 & 12LX08 & 12LX09 & $12 \mathrm{LX} 10$ & 12LX11 & 12LX12 & 12LX13 & 12LX14 \\
\hline $\mathrm{SiO}_{2}$ & 71.6 & 72.2 & 72.3 & 72.9 & 70.9 & 71.0 & 71.4 & 71.3 & 72.4 \\
\hline $\mathrm{TiO}_{2}$ & 0.57 & 0.53 & 0.58 & 0.49 & 0.5 & 0.6 & 0.61 & 0.63 & 0.61 \\
\hline $\mathrm{Al}_{2} \mathrm{O}_{3}$ & 11.8 & 11.7 & 11.7 & 11.9 & 12.7 & 12.4 & 12.5 & 12.3 & 12.1 \\
\hline $\mathrm{Fe}_{2} \mathrm{O}_{3} \mathrm{~T}$ & 3.34 & 5.69 & 6.24 & 4.53 & 4.01 & 5.51 & 5.61 & 5.64 & 3.8 \\
\hline $\mathrm{MnO}$ & 0.03 & 0.02 & 0.01 & 0.03 & 0.03 & 0.03 & 0.01 & 0.03 & 0.04 \\
\hline $\mathrm{MgO}$ & 0.06 & 0.39 & 0.11 & 0.53 & 0.76 & 0.19 & 0.14 & 0.18 & 0.09 \\
\hline $\mathrm{CaO}$ & 1.95 & 0.26 & 0.29 & 0.23 & 1.05 & 0.28 & 0.27 & 0.27 & 1.49 \\
\hline $\mathrm{Na}_{2} \mathrm{O}$ & 2.92 & 1.94 & 2.98 & 1.90 & 1.90 & 2.20 & 2.33 & 2.17 & 2.92 \\
\hline $\mathrm{K}_{2} \mathrm{O}$ & 5.11 & 6.16 & 4.95 & 6.05 & 6.38 & 6.69 & 6.17 & 6.64 & 5.18 \\
\hline $\mathrm{P}_{2} \mathrm{O}_{5}$ & 0.13 & 0.10 & 0.14 & 0.09 & 0.10 & 0.15 & 0.14 & 0.14 & 0.15 \\
\hline LOI & 2.11 & 1.14 & 0.79 & 1.33 & 1.95 & 0.85 & 0.98 & 0.88 & 1.53 \\
\hline TOTAL & 99.6 & 100.1 & 100.1 & 99.9 & 100.3 & 99.9 & 100.1 & 100.2 & 100.3 \\
\hline $\mathrm{A} / \mathrm{CNK}$ & 0.85 & 1.13 & 1.08 & 1.18 & 1.07 & 1.09 & 1.13 & 1.10 & 0.92 \\
\hline $\mathrm{Mg}^{\#}$ & 4.02 & 13.80 & 3.95 & 21.40 & 30.60 & 7.44 & 5.50 & 6.92 & 5.23 \\
\hline $\mathrm{Li}$ & 6.85 & 12.20 & 3.04 & 8.16 & 10.20 & 1.95 & 3.75 & 2.09 & 5.61 \\
\hline $\mathrm{Be}$ & 1.61 & 2.84 & 2.47 & 2.56 & 2.32 & 1.33 & 1.37 & 1.39 & 1.73 \\
\hline $\mathrm{Sc}$ & 9.30 & 9.10 & 9.71 & 8.92 & 9.95 & 8.64 & 9.61 & 9.00 & 9.71 \\
\hline $\mathrm{V}$ & 18.3 & 5.92 & 27.6 & 4.64 & 2.91 & 16.9 & 31.3 & 18.8 & 21.6 \\
\hline $\mathrm{Cr}$ & 6.91 & 5.76 & 12.5 & 4.08 & 4.25 & 8.55 & 9.17 & 10.0 & 7.83 \\
\hline Co & 74.4 & 90.1 & 105 & 58.7 & 63.5 & 106 & 69.4 & 73.5 & 99.2 \\
\hline $\mathrm{Ni}$ & 2.68 & 2.73 & 6.17 & 2.14 & 2.19 & 4.17 & 3.97 & 4.51 & 3.66 \\
\hline $\mathrm{Cu}$ & 3.43 & 10.3 & 7.93 & 16.3 & 3.07 & 5.98 & 8.00 & 7.09 & 3.86 \\
\hline $\mathrm{Zn}$ & 20.8 & 56.7 & 42.7 & 71.9 & 64.3 & 46.1 & 31.2 & 44.9 & 25.7 \\
\hline $\mathrm{Ga}$ & 17.3 & 21.2 & 15.9 & 21.5 & 26.1 & 19.2 & 23.3 & 18.5 & 19.3 \\
\hline $\mathrm{Ge}$ & 1.05 & 1.83 & 0.98 & 1.40 & 1.58 & 0.83 & 0.88 & 0.83 & 1.02 \\
\hline $\mathrm{Rb}$ & 139 & 160 & 127 & 156 & 157 & 191 & 181 & 186 & 143 \\
\hline $\mathrm{Sr}$ & 82.2 & 46.8 & 80.1 & 52.1 & 49.5 & 71.6 & 52.5 & 72.3 & 77.2 \\
\hline $\mathrm{Y}$ & 63.9 & 106 & 68.4 & 86.6 & 104 & 54.1 & 52.8 & 62.6 & 66.5 \\
\hline $\mathrm{Zr}$ & 540 & 819 & 557 & 739 & 802 & 560 & 579 & 586 & 560 \\
\hline $\mathrm{Nb}$ & 26.6 & 36.3 & 26.0 & 34.7 & 36.9 & 27.7 & 28.4 & 28.7 & 27.0 \\
\hline Cs & 0.39 & 1.30 & 0.40 & 1.21 & 0.69 & 0.55 & 0.81 & 0.54 & 0.48 \\
\hline $\mathrm{Ba}$ & 1734 & 1383 & 1784 & 1427 & 1556 & 2356 & 1944 & 2420 & 1700 \\
\hline $\mathrm{La}$ & 105 & 239 & 41.4 & 139 & 205 & 28.1 & 26.5 & 26.3 & 98.7 \\
\hline $\mathrm{Ce}$ & 215 & 466 & 101 & 302 & 419 & 73.8 & 78.7 & 76.3 & 205 \\
\hline $\operatorname{Pr}$ & 24.9 & 61.2 & 10.6 & 36.2 & 52.3 & 7.87 & 7.54 & 7.48 & 23.7 \\
\hline $\mathrm{Nd}$ & 94.4 & 233 & 41.2 & 133 & 198 & 32.4 & 31.3 & 30.9 & 90.2 \\
\hline $\mathrm{Sm}$ & 16.5 & 39.6 & 8.37 & 23.5 & 34.3 & 7.51 & 7.04 & 7.43 & 16.1 \\
\hline $\mathrm{Eu}$ & 2.53 & 6.08 & 1.34 & 3.59 & 5.39 & 1.24 & 1.18 & 1.28 & 2.50 \\
\hline $\mathrm{Gd}$ & 13.5 & 31.7 & 8.11 & 18.5 & 27.9 & 7.27 & 6.90 & 7.69 & 13.6 \\
\hline $\mathrm{Tb}$ & 1.89 & 4.07 & 1.39 & 2.64 & 3.63 & 1.29 & 1.25 & 1.44 & 1.93 \\
\hline Dy & 11.1 & 20.9 & 9.83 & 15.3 & 19.0 & 8.54 & 8.43 & 9.69 & 11.3 \\
\hline Ho & 2.17 & 3.62 & 2.23 & 3.02 & 3.39 & 1.83 & 1.81 & 2.13 & 2.22 \\
\hline $\mathrm{Er}$ & 6.62 & 10.4 & 7.32 & 9.16 & 9.87 & 5.86 & 5.75 & 6.81 & 6.78 \\
\hline $\mathrm{Tm}$ & 1.00 & 1.48 & 1.14 & 1.31 & 1.36 & 0.89 & 0.86 & 1.00 & 0.98 \\
\hline $\mathrm{Yb}$ & 6.75 & 9.78 & 7.74 & 8.69 & 8.97 & 6.12 & 5.86 & 6.88 & 6.65 \\
\hline $\mathrm{Lu}$ & 1.01 & 1.45 & 1.18 & 1.32 & 1.34 & 0.96 & 0.92 & 1.06 & 1.00 \\
\hline $\mathrm{Hf}$ & 12.8 & 18.3 & 13.2 & 17.5 & 18.7 & 13.8 & 14.0 & 14.2 & 13.6 \\
\hline $\mathrm{Ta}$ & 1.45 & 1.80 & 1.33 & 1.69 & 1.82 & 1.51 & 1.51 & 1.53 & 1.48 \\
\hline $\mathrm{Pb}$ & 5.91 & 5.40 & 12.3 & 4.90 & 3.42 & 8.73 & 7.74 & 9.33 & 6.31 \\
\hline $\mathrm{Th}$ & 16.7 & 12.7 & 16.7 & 12.5 & 13.1 & 16.2 & 15.9 & 16.7 & 16.4 \\
\hline $\mathrm{U}$ & 2.68 & 1.85 & 2.65 & 1.75 & 2.35 & 2.65 & 2.24 & 2.98 & 2.62 \\
\hline$\delta E u$ & 0.52 & 0.52 & 0.50 & 0.53 & 0.53 & 0.51 & 0.52 & 0.52 & 0.52 \\
\hline$\Sigma$ REE & 515.0 & 1133.4 & 254.0 & 709.9 & 995.1 & 188.5 & 188.2 & 196.3 & 480.4 \\
\hline $\mathrm{T}_{\mathrm{Zr}}\left({ }^{\circ} \mathrm{C}\right)$ & 877 & 964 & 914 & 958 & 951 & 913 & 922 & 919 & 893 \\
\hline
\end{tabular}




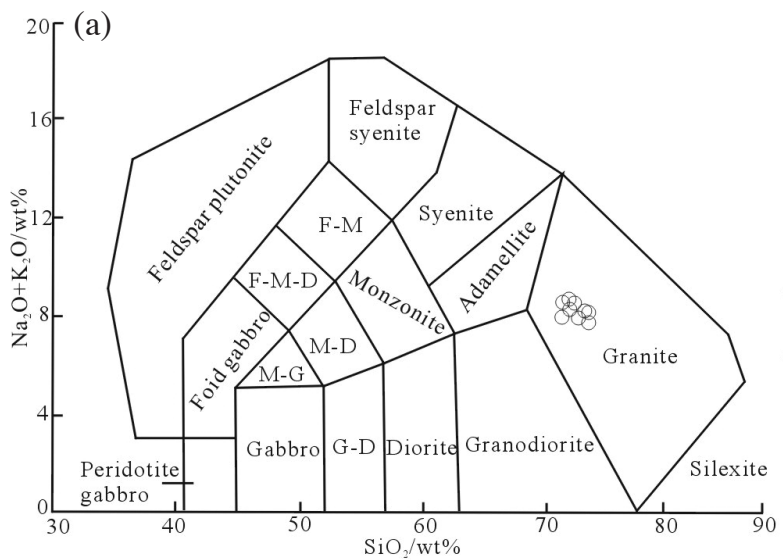

(b)

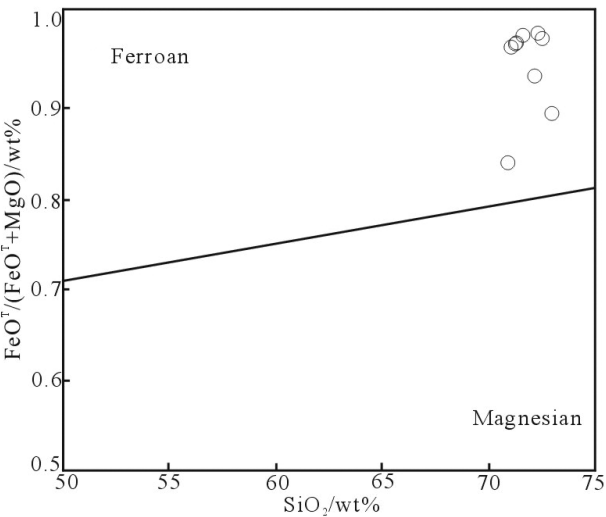

Fig. 6. (a) TAS diagram for granite in Baojiashan section (after Middlemost 1994); (b) $\mathrm{FeO}^{\mathrm{T}} /\left(\mathrm{FeO}^{\mathrm{T}}+\mathrm{MgO}\right.$ )-SiO${ }_{2}$ diagram for Baojiashan granite (after Frost et al. 2001).

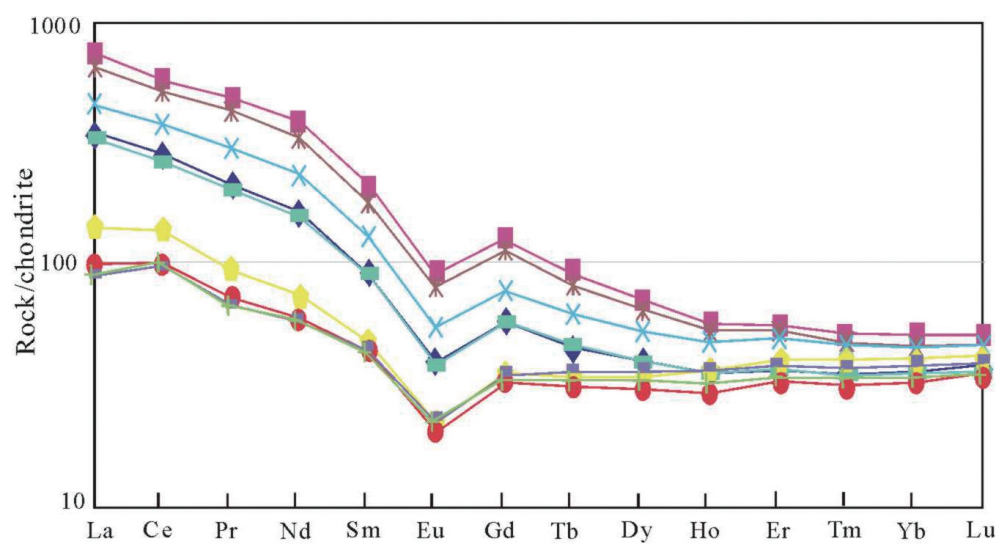

Fig. 7. Chondrite-normalized REE-pattern diagram for Baojiashan granite (chondrite data from Boynton 1984). (Color online only)

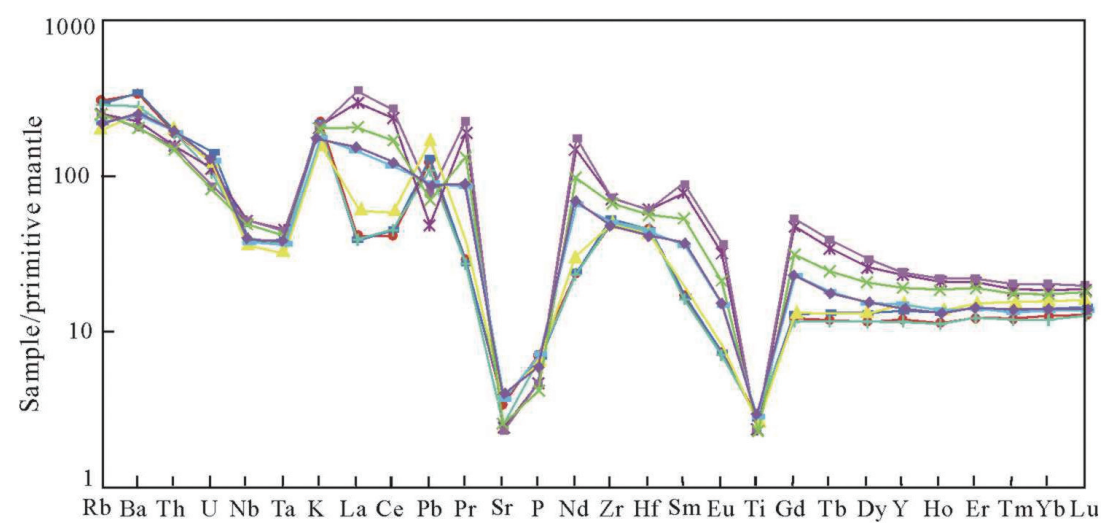

Fig. 8. Primitive-mantle normalized spider diagram for Baojiashan granite (primitive-mantle data from Sun and McDonough 1989). (Color online only)

Table 3. Sm-Nd isotopic composition of Baojiahsan granite.

\begin{tabular}{c|cccccccc}
\hline Sample & $\mathbf{S m}(\mathbf{p p m})$ & $\mathbf{N d}(\mathbf{p p m})$ & ${ }^{147} \mathbf{S m} /{ }^{144} \mathbf{N d}$ & ${ }^{143} \mathbf{N d} /{ }^{144} \mathbf{N d}$ & $\mathbf{2 \sigma}$ & $\boldsymbol{\varepsilon}_{\mathbf{N d}}(\mathbf{t})$ & $\mathbf{t}_{\text {DM1 }}(\mathbf{G a})$ & $\mathbf{t}_{\text {DM2 }}(\mathbf{G a})$ \\
\hline $12 \mathrm{LX} 11$ & 5.79 & 32.3 & 0.1083 & 0.511341 & 0.000011 & -22.5 & 2.60 & 2.45 \\
$12 \mathrm{LX} 12$ & 3.80 & 22.6 & 0.1016 & 0.511456 & 0.000005 & -20.0 & 2.29 & 2.29 \\
\hline
\end{tabular}


Liupanshan fault system. All of these granites are characterized by high $\mathrm{Si}$ and alkalis, with high $\mathrm{Rb} / \mathrm{Sr}$ and $\mathrm{Ga} / \mathrm{Al}$, relative enrichments in LILEs, and depletions in HFSEs, $\mathrm{P}$, and $\mathrm{Sr}$. In addition, they show similar REE and trace element behaviors. The average value of $10000 \times \mathrm{Ga} / \mathrm{Al}$ is greater than 2.6, higher than that of I-type (mean $10000 \times$ $\mathrm{Ga} / \mathrm{Al}=2.1)$ and $\mathrm{S}$-type granites (mean $10000 \times \mathrm{Ga} / \mathrm{Al}=$ 2.28; Whalen et al. 1987). The Baojiashan, Duanjiaxia, and Shizuizi granites plot as A-type granites in the discrimination diagrams $(10000 \times \mathrm{Ga} / \mathrm{Al})-\mathrm{Nb}$ and $(10000 \times \mathrm{Ga} / \mathrm{Al})-\mathrm{Zr}$. Mean $\mathrm{Rb} / \mathrm{Sr}=2.6$, similar to that of A-type granite $(\mathrm{Rb} / \mathrm{Sr}$ $=3.52)$ and higher than that of I-type $(\mathrm{Rb} / \mathrm{Sr}=0.61)$ and S-type granites $(\mathrm{Rb} / \mathrm{Sr}=1.81$; Whalen et al. 1987). In addition, $\mathrm{Th} / \mathrm{U}$ and $\mathrm{Nb} / \mathrm{Ta}$ values, and low $\mathrm{Sr}$, medium $\mathrm{Rb}$, and high $\mathrm{Rb} / \mathrm{Sr}$ suggest that the granites are A-type, and not island-arc-type or collision-type (Whalen et al. 1987). Furthermore, $\mathrm{Nb} / \mathrm{Y}=0.34-0.54$, again characteristic of A-type granite (Whalen et al. 1987), and $\mathrm{Y} / \mathrm{Nb}<1.2$ (Deng et al. 2004), which suggests that the granites are $A_{1}$-type. Thus, the granites possess the geochemical characteristics of nonorogenic alkaline rocks (Bourne 1986) and can be classified as within-plate A-type granites (WPG; Fig. 9) that formed in a continental rift setting (Yu et al. 1997).

Partial melting experiments demonstrate that some Atype granites can be produced from the shallow continental crust (Zhang et al. 2010). The $\mathrm{Al}_{2} \mathrm{O}_{3}$, Eu and $\mathrm{SiO}_{2}$ do not have obvious negative correlation suggesting that plagioclase did not fractionate during the crystallization of the parental magma. While, the depletion of $\mathrm{Sr}$ and $\mathrm{Eu}$ in the spider diagram (Fig. 8) indicates the plagioclase was the main residual phase in the magmatic source. Low ratios of $\mathrm{La} / \mathrm{Yb}$ and $\mathrm{Sr} / \mathrm{Y}$, high contents of $\mathrm{Yb}$ and $\mathrm{Y}$ show that the granitic magma was derived from a garnet-poor source. The minimum pressure of plagioclase disappearance is $1.2 \mathrm{GPa}$ and the minimum pressure for the appearance of garnet is $0.8-1.0 \mathrm{GPa}$ (Defant and Dmmmond 1990; Douce 1997), thus the granite source was probably less $0.8 \mathrm{GPa}$. The magma formation depth is less than $30 \mathrm{~km}$ (Zhang et al. 2010). It is believed that zircon saturation temperatures represent the near-liquidus temperature of granitic rocks (Watson and Harrison 1983). Miller et al. (2003) calculated a series of zircon saturation temperatures and discovered that there are probably two types of granites. The so called "hot granites" have $T_{Z r}\left({ }^{\circ} \mathrm{C}\right)$ temperatures $>800^{\circ} \mathrm{C}$ whereas the "cold granites" have $T_{Z r}\left({ }^{\circ} \mathrm{C}\right)$ temperatures $<800^{\circ} \mathrm{C}$. The difference in the temperature estimates is attributed to the amount of inherited zircon. The "hot granites" generally do not have significant zircon inheritance but the "cold granites" do. The $T_{z r}\left({ }^{\circ} \mathrm{C}\right)$ temperatures were calculated for the Baojiashan granite.

$T_{Z r}\left({ }^{\circ} \mathrm{C}\right)=12900 /[2.95+0.85 \mathrm{M}+\ln (496000 / Z r)]-273.15(1)$

In this equation, $\mathrm{M}$ is the atom fraction normalizing parameter. $\mathrm{Let} \mathrm{Si}+\mathrm{Al}+\mathrm{Fe}+\mathrm{Mg}+\mathrm{Ca}+\mathrm{Na}+\mathrm{K}+\mathrm{P}=1$, and $\mathrm{M}=(2 \mathrm{Ca}+\mathrm{K}+\mathrm{Na}) /(\mathrm{Si} \times \mathrm{Al})$. This equation yields crystallization temperatures of $880-960^{\circ} \mathrm{C}$. Thus, we propose that the Baojiashan granite is high-temperature and shallowsource A-type granite.

\subsection{Source of the Baojiashan Granite}

Whole rock Sm-Nd isotopic composition can well reveal the source of rocks. The positive $\varepsilon_{\mathrm{Nd}}(t)$ of granite shows the forming material source is the juvenile crust. The negative $\varepsilon_{N d}(t)$ reveals the granitic magma comes from the ancient crust (Depaolo 1981). Baojiashan granite has negative $\varepsilon_{\mathrm{Nd}}(t)$ of -22.5 to -20.0 . The two-stage model ages are 2.29 - $2.45 \mathrm{Ga}$ which are obviously older than the formation ages of Baojiashan granite. The two-stage model ages suggest that the magma of Baojiashan granite is the product of the NCC basement partial melting.
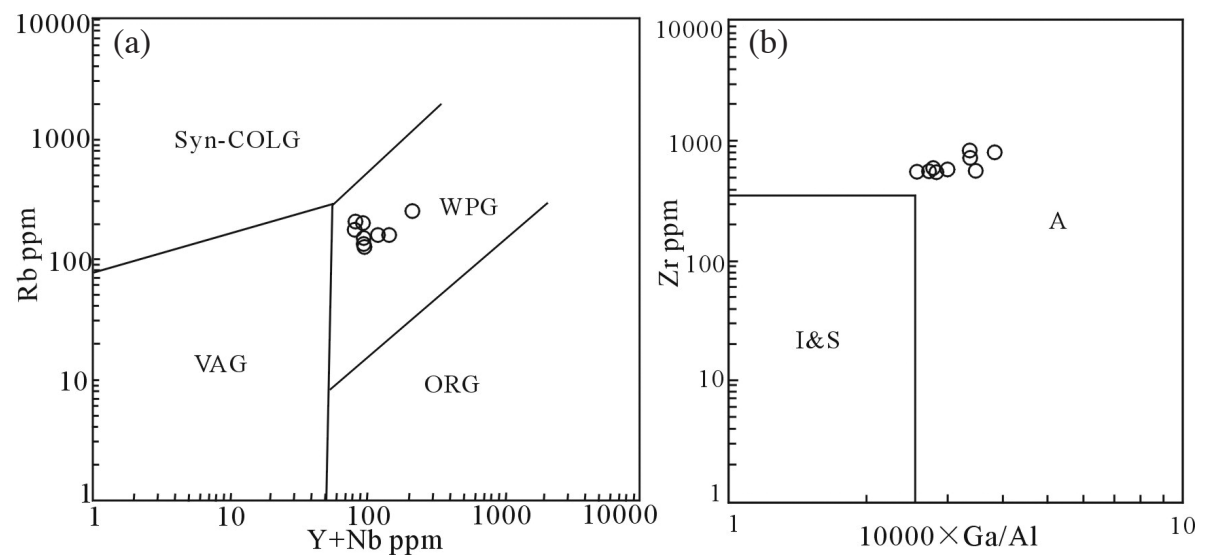

Fig. 9. (a) Tectonic setting discrimination diagrams for Baojiashan granite (after Pearce 1996); (b) Discriminant diagram of A-type granitoid (after Whalen et al. 1987)

Note: A: A-type granite; I: I-type granite; S: S-type granite. 
The $\mathrm{Th} / \mathrm{U}$ ratio ranges from $5.58-7.16$, and $\mathrm{Nb} / \mathrm{Ta}=$ 18.37 - 20.29, indicating that the rocks have a middle-lower crust affinity $(\mathrm{Th} / \mathrm{U}=6, \mathrm{Nb} / \mathrm{Ta}=16.5$; Rudnick and Gao 2003), and may have been derived from the partial melting of a middle-lower crustal source. High LILEs and a strong depletion in HFSEs are typical of granites derived from a crustal source, and suggest that the granites are associated with crustal thinning (Whalen et al. 1987; Eby 1990; Zhang 2013).

\subsection{Tectonomagmatic Environment of the Baojiahsan Granite}

In contrast to the increasing thermal modal of the crust extrusion, the partial melting of lower crustal material in an extensional tectonic setting requires an external heat supply. Crustal thinning may be accompanied by mantle upwelling and the emplacement of mafic magmas. The mantle material acts as a heat source to drive partial melting. Low pressure, high temperature, and anhydrous conditions are necessary for the formation of A-type granites (Zhang et al. 2010). Because the duration of the crust tinning and extension is limted, A-type granites are typically not voluminous and widespread, which may explain why few Paleoproterozoic granites have been mapped in the Helan aulacogen.

Similar ages have been reported for the Shizuizi granites (1778 $\pm 14 \mathrm{Ma}$; Wang et al. 2012; $1803 \pm 15 \mathrm{Ma}$; Gao et al. 2013), the Duanjiaxia granite (1802 $\pm 10 \mathrm{Ma}$;), and the Baojiashan granite $(1738 \pm 15 \mathrm{Ma})$. These ages (about $1750 \mathrm{Ma}$ ) indicate that the granites are the coeval products of late Paleoproterozoic magmatism in the Southwestern margin of the NCC. Previous studies have examined there were plenty of the coeval rocks in other part of the NCC, such as Xiong'er (southern margin of the NCC), Taihang (central region of the NCC), Yan-Liao (northern margin of the NCC) and Jing-Ji (eastern margin of the NCC) (Peng et al. 2004; Yang et al. 2005, 2007; Xu et al. 2007; Zhao et al. 2015). Peng et al. (2004) and Zhao et al. (2004) dated a dacite-rhyolite assemblage in Xiong'er Group, and determined their age of 1.8 - 1.75 Ga. Hou et al. (2010) and $\mathrm{Hu}$ et al. (2010) obtained $\sim 1.78 \mathrm{Ga}$ ages for basic dikes in the Xiong'er and Zhongtiao area. Zhao et al. (2007) determined the ages of anorthosite-alkali granite-rapakivi granite with $1.75-1.68 \mathrm{Ga}$. This near coeval rock associated is thought to be related to a mantle plume and the breakup of Columbia supercontinent (Peng et al. 2007). Yang et al. (2005) obtained the age of Beijing Miyun rapakivi granite with 1.68 $\mathrm{Ga}$, and indicated the rapakivi granite was due to extension within the NCC.

The older zircons with ages of $1850 \mathrm{Ma}$ in the Baojiashan granite were interpreted as inherited zircons. You et al. (2014) obtained a weighted mean age of $1846 \pm 19 \mathrm{Ma}$ for the Duanjiaxia granite. The ages (about $1850 \mathrm{Ma}$ ) may indicate another tectonic event. The coeval rocks have been examined in the NCC. Liaodong Tongkuanggou alkaline pluton had the age of $1.88 \mathrm{Ga}$. Geochemical characteristics of the pluton indicated a post-collisional extensional setting (Yang et al. 2007). The formation age of Lüliang Yunzhongshan granite is $1.8 \mathrm{Ga}$ which provids direct evidence for constraints on the ending time of the orogeny and the starting of the NCC breakup (Geng et al. 2004). The ages $1.85 \mathrm{Ga}$ are related to post-collisional thinning of the NCC, and the ending time is about $1.8 \mathrm{Ga}$. After $1.8 \mathrm{Ga}$, mantle plume activity caused uplift and extension in the NCC (Zhao et al. 2007).

Previous studies have examined the extensional tectonic events of the NCC and the formation of aulacogens in the late Paleoproterozoic (e.g., Li et al. 2000; Zhai and Peng 2007, 2014; Zhao et al. 2007; Gao et al. 2013). These extensional events and aulacogens may have resulted from plume activity at $\sim 1.8 \mathrm{Ga}$ (Zhao et al. 2005, 2007). At this time, the upwelling of mantle material caused uplift of the NCC, resulting in lithospheric thinning, partial melting, and the development of a rift system (Zhao et al. 2007; Zhai et al. 2014). East-West-trending rifts ultimately evolved into the Qinling-Qilian trough, and the NNE- to NE-trending rifts (Helan, Xiong'er, and Yanliao rifts) evolved into aulacogens (Che et al. 2011). Earlier studies on the Xiong'er and Yanliao aulacogens suggest that extension was associated with breakaway of the NCC from the Columbia Supercontinent (Yang et al. 2005; Zhao et al. 2007; Cui et al. 2010). Furthermore, the linear distribution of the A-type granites suggests that not only the $1.8 \mathrm{Ga}$ magmatism was accompanied by rifting along the WSW margin of the NCC at the end of the Paleoproterozoic. During that period, the crustlithospheric thinning and asthenospheric mantle upwelling had cover the whole craton, so the Helan-Liupan area had seen the same geological events. The junction of the rift system may be located in the southwestern part of Baoji City. With the evolution of the rift system, the northward branch of the rift extended into the NCC and reached the LiupanHelan area. The south branch connected with the QinlingQilian trough, which formed part of the Qinling-Qilian rift (Fig. 1) (Sun and Liu 1983; He 1993; Che et al. 2011).

The formation ages and geochemical data suggest the southwestern margin of the NCC formed in an extensional tectonic setting in the late Paleoproterozoic. This tectonic setting is consistent with the evolution of the Helan aulacogen, although the occurrence of related magmatic rocks has yet to be confirmed. Thus, we propose that the Baojiashan granite porphyry, and the Duanjiaxia and Shizuizi granites were associated with the development of the Helan aulacogen, and may later have been affected and exposed by Mesozoic-Cenozoic movement on the Liupanshan Fault.

\section{CONCLUSIONS}

(1) U-Pb geochronology shows that the Baojiashan granite 
porphyry formed at $1738 \mathrm{Ma}$. This age is consistent with that of the Duanjiaxia and Shizuizi granites, both of which are located at the southwestern margin of the NCC.

(2) The Baojiashan, Duanjiaxia, and Shizuizi granites are A-type, indicating they formed in an extensional environment during the Paleoproterozoic, and that their formation was associated with the development of the Helan aulacogen.

(3) The Luipanshan fault system was active during the Mesozoic-Cenozoic. Its orientation controlled the spatial distribution of the Baojiashan, Duanjiaxia, and Shizuizi granites, but fault activity did not cause magmatism.

(4) The Helan aulacogen formed in the Helanshan area, and at its southernmost part is connected with the QinlingQilian trough; together, these structures formed a large rift system in the inner NCC during the late Paleoproterozoic.

Acknowledgements Financial support for this study was jointly provided by Innovative Research Team in University (Grant IRT1281) and Supported by MOST Special Fund from the State Key Laboratory of Continental Dynamics, Northwest University. We are grateful to editors ChungPai Chang and Kun-Lung Wang for their assistance for the paper. Greg Shellnutt and another anonymous reviewer are thanked for their constructive comments which greatly improved the paper.

\section{REFERENCES}

Bourne, J. H., 1986: Geochemistry of the felsic metavolcanic rocks of the Wakeham Group: A metamorphosed peralkaline suite from the eastern Grenville Province, Quebec, Canada. Can. J. Earth Sci., 23, 978-984, doi: 10.1139/e86-099. [Link]

Boynton, W. V., 1984: Cosmochemistry of the rare Earth elements: Meteorite studies. In: Henderson, P. (Ed.), Rare Earth Element Geochemistry: Development in Geochemistry, Elsevier, Amsterdam, 63-114, doi: 10.1016/b978-0-444-42148-7.50008-3. [Link]

Che, F. X., 1963: Measurement map of northwest Longxian city.

Che, Z. C. and R. S. Wang, 1985: An investigation on Cenozoic volcanism in Weihe Basin. J. NW. Univ., 49, 82-88.

Che, Z. C., J. H. Luo, and L. Liu, 2011: China and Its Adjacent Area Geotectonics, Science Press, Beijing, 26-32, 239-246.

Cui, M. L., B. L. Zhang, P. Peng, L. C. Zhang, X. L. Shen, Z. H. Guo, and X. F. Huang, 2010: Zircon/baddeleyite $\mathrm{U}-\mathrm{Pb}$ dating for the Paleo-proterozoic intermediateacid intrusive rocks in Xiaoshan Mountains, west of Henan Province and their constraints on the age of the Xiong'er Volcanic Province. Acta Petrol. Sin., 26,
1541-1549.

Defant, M. J. and M. S. Dmmmond, 1990: Derivation of some modern arc magmas by melting of young subducted lithosphere. Nature, 347, 662-665, doi: 10.1038/347662a0. [Link]

Deng, J. F., Z. H. Luo, S. G. Su, X. X. Mo, B. S. Yu, X. Y. Lai, and H. W. Chen, 2004: Petrogenesis, Tectonic Setting and Metallogenesis, Geological Publishing House, Beijing, 32-40.

DePaolo, D. J., 1981: Neodymium isotopes in the Colorado Front Range and crust-mantle evolution in the Proterozoic. Nature, 291, 193-196, doi: 10.1038/291193a0. [Link]

Dong, C. Y., S. J. Wang, D. H. Liu, J. G. Wang, H. Xie, W. Wang, Z. Y. Song, and Y. S. Wan, 2010: Late Palaeoproterozoic crustal evolution of the North China Craton and formation time of the Jingshan Group: Constraints from SHRIMP U-Pb zircon dating of meta-intermediate-basic intrusive rocks in eastern Shandong Province. Acta Petrol. Sin., 27, 1699-1706.

Douce, A. E. P., 1997: Generation of metaluminous A-type granites by low pressure melting of calc-alkaline granitoids. Geology, 25, 743-746, doi: 10.1130/0091-7613(1997)025<0743:gomatg >2.3.co;2. [Link]

Eby, G. N., 1990: The A-type granitoids: A review of their occurrence and chemical characteristics and speculations on their petrogenesis. Lithos, 26, 115-134, doi: 10.1016/0024-4937(90)90043-z. [Link]

Frost, B. R., C. G. Barnes, W. J. Collins, R. J. Arculus, D. J. Ellis, and C. D. Frost, 2001: A geochemical classification for granitic rocks. J. Petrol., 42, 2033-2048, doi: 10.1093/petrology/42.11.2033. [Link]

Gao, L.Z., X. Z. Ding, Q. Cao, and C. H. Zhang, 2010: New Geological time scale of Late Precambrian in China and geochronology. Chin. Geol., 37, 1014-1020.

Gao, S. L., 2001: Evolution of the western margin of the Ordos Basin stratigraphy and tectonic in Mesozoic. Institute of Geology and Geophysics, Chinese Academy of Sciences, Beijing, 34-52.

Gao, S. L., J. Y. Lin, and Y. J. Lu, 2013: Formation epoch and its geological implications of Paleoprotozoic Aype granite in Shizuizi of Jingyuan County, Ningxia Province. Acta Petrol. Sin., 29, 2676-2684.

Geng, Y. S., C. H. Yang, B. Song, and Y. S. Wan, 2004: Post-orogenic granites with an age of $1800 \mathrm{Ma}$ in Luliang area, North China Craton: constraints from isotopic geochronology and geochemistry. Geological Journal of China Universities, 10, 477-487.

Geng, Y. S., X. S. Wang, C. M. Wu, and X. W. Zhou, 2010: Late-Paleoproterozoic tectonothermal events of the metamorphic basement in Alxa area: Evidence from geochronology. Acta Petrol. Sin., 26, 1159-1170.

Günther, D. and B. Hattendorf, 2005: Solid sample analysis using laser ablation inductively coupled plasma mass 
spectrometry. TrAC, Trends in Analytical Chemistry, 24, 255-265, doi: 10.1016/j.trac.2004.11.017. [Link]

He, Y. H., Y. Sun, L. Chen, H. P. Li, H. L. Yuan, and X. M. Liu, 2005: Zircon U-Pb chronology of Longshan complex by LA-ICP-MS and its geological significance. Acta Petrol. Sin., 21, 127-136, doi: 10.3321/j. issn:1000-0569.2005.01.012. [Link]

He, Z. J., 1993: Review of aulacogen. Geological Science and Technology Information, 12, 8-12.

Hou, G. T., C. Wang, and L. Li, 2010: Magnetic fabric evidences for the late Paleoproterozoic mafic dyke swarm emplacement, southern margin of the North China Craton. Acta Petrol. Sin., 26, 318-324.

Hu, G. H., J. L. Hu, W. Chen, and T. P. Zhao, 2010: Geochemistry and tectonic setting of the $1.78 \mathrm{Ga}$ mafic dyke swarms in the Mt. Zhongtiao and Mt. Song areas, the southern margin of the North China Craton. Acta Petrol. Sin., 26, 1563-1576.

Hua, H. and S.Y. Qiu, 2001: Three mesoproterozoic stromatolite assemblages in the Helan MT., Ningxia and their biostratigraphic siginificance. J. Stratigr., 25, 307-311.

Jahn, B. M. and K. C. Condie, 1995: Evolution of the Kaapvaal Craton as viewed from geochemical and Sm$\mathrm{Nd}$ isotopic analyses of intracratonic pelites. Geochim. Cosmochim. Acta, 59, 2239-2258, doi: 10.1016/00167037(95)00103-7. [Link]

Jiang, Z. S., G. D. Wang, L. L. Xiao, C. R. Diwu, J. S. Lu, and C. M. Wu, 2011: Paleoproterozoic metamorphic P-T-t path and tectonic significance of the Luoning metamorphic complex at the southern terminal of the Trans- North China Orogen, Henan Province. Acta Petrol.Sin., 27, 3701-3717.

Li, J. H., X. L. Qian, G. T. Hou, S. W. Liu, and J. Chen, 2000: Late Palaeoproterozoic to early Mesoproterozoic tectonic framework and major tectono-thermal episodes of North China: New interpretation of "Luliang Orogeny”. Earth Sci. J. China Univ. Geosci., 25, $15-20$.

Li, Z. H., X. M. Liu, Y. P. Dong, and Z. B. Xiao, 2013: Geochemistry and zircon U-Pb age of the Paleoproterozoic syn-collisional granites in Helanshan region and its geological significance. Acta Petrol. Sin., 29, 2405-2415.

Liang, X. R., G. J. Wei, X. H. Li, and Y. Liu, 2003: Precise measurement of ${ }^{143} \mathrm{Nd} /{ }^{144} \mathrm{Nd}$ and $\mathrm{Sm} / \mathrm{Nd}$ ratios using multiple-collectors inductively coupled plasma-mass spectrometer (MC-ICPMS). Geochimica, 32, 91-96.

Liu, C. H., F. L. Liu, and G. C. Zhao, 2013: Provenance and tectonic setting of the Jiehekou Group in the Lüliang Complex: Constraints from zircon $\mathrm{U}-\mathrm{Pb}$ age and $\mathrm{Hf}$ isotopic studies. Acta Petrol. Sin., 29, 517-532.

Ludwig, K. R., 2001: Users Manual for Isoplot/Ex Rev. 2.49, Berkeley Geochronology Centre Special Publi- cation, 1-56.

Middlemost, E. A. K., 1994: Naming materials in the magma/igneous rock system. Earth-Sci. Rev., 37, 215-224, doi: 10.1016/0012-8252(94)90029-9. [Link]

Miller, C. F., S. M. McDowell, and R. W. Mapes, 2003: Hot and cold granites? Implications of zircon saturation temperatures and preservation of inheritance. Geology, 31, 529-532, doi: 10.1130/0091-7613(2003)031<0529: hacgio>2.0.co;2. [Link]

Pearce, J. A., 1996: Sources and settings of granitic rocks. Episodes, 19, 120-125.

Peng, P., M. G. Zhai, H. F. Zhang, T. P. Zhao, and Z. Y. Ni, 2004: Geochemistry and geological significance of the $1.8 \mathrm{Ga}$ mafic dyke swarms in the North China Craton: An example from the juncture of Shanxi, Hebei and Inner Mongolia. Acta Petrol. Sin., 20, 439-456.

Peng, P., M. G. Zhai, J. H. Guo, T. Kusky, and T. P. Zhao, 2007: Nature of mantle source contributions and crystal differentiation in the petrogenesis of the $1.78 \mathrm{Ga}$ mafic dykes in the central North China craton. Gondwana Research, 12, 29-46, doi: 10.1016/j.gr.2006.10.022. [Link]

Rudnick, R. L. and S. Gao, 2003: Composition of the continental crust. In: Holland, H. D. and K. K. Turekian (Eds.), Treatise on Geochemistry, Volume 3: The Crust, Elsevier, 1-64, doi: 10.1016/B0-08-0437516/03016-4. [Link]

Sun, G. F. and J. P. Liu, 1983: Helan aulacogen and front basin and their evolution. Oil Gas Geol., 4, 236-245, doi: 10.11743/ogg19830301. [Link]

Sun, S. S. and W. F. McDonough, 1989: Chemical and isotopic systematics of oceanic basalts: Implications for mantle composition and processes. Geol. Soc. Lond. Spec. Publ., 42, 313-345, doi: 10.1144/gsl. sp.1989.042.01.19. [Link]

Wang, C., X. D. Ma, and Z. R. Lang, 2012: Zircon SHRIMP $\mathrm{U}-\mathrm{Pb}$ dating of granite porphyry at Shizuizi in southern section of Liupanshan and its significance. Ningxia Engineering Technology, 11, 335-337.

Wang, T.H., 1995: Evolutionary characteristics of geological structure and oil-gas accumulation in Shanxi-Shaanxi area. J. Geol. Min. Res. North China, 10, 283-304.

Watson, E. B. and T. M. Harrison, 1983: Zircon saturation revisited: Temperature and composition effects in a variety of crustal magma types. Earth Planet. Sci. Lett., 64, 295-304, doi: 10.1016/0012-821X(83)90211-X. [Link]

Wei, G. J., X. R. Liang, X. H. Li, and Y. Liu, 2002: Precise measurement of $\mathrm{Sr}$ isotopic composition of liquid and solid base using (LP) MC-ICPMS. Geochimica, 31, 295-299.

Whalen, J. B., K. L. Currie, and B. W. Chappell, 1987: Atype granites: Geochemical characteristics, discrimination and petrogenesis. Contrib. Mineral. Petrol., 95, 
407-419, doi: 10.1007/BF00402202. [Link]

Wiedenbeck, M., P. Alle, F. Corfu, W. L. Griffin, M. Meier, F. Oberli, A. Von Quadt, and J. C. Roddick, and W. Spiegel, 1995: Three natural zircon standards for U$\mathrm{Th}-\mathrm{Pb}, \mathrm{Lu}-\mathrm{Hf}$, trace element and ree analyses. Geostand. Geoanal. Res., 19, 1-23, doi: 10.1111/j.1751908X.1995.tb00147.x. [Link]

Wiedenbeck, M., J. M. Hanchar, W. H. Peck, P. Sylvester, J. Valley, M. Whitehouse, A. Kronz, Y. Morishita, L. Nasdala, J. Fiebig, I. Franchi, J.-P. Girard, R. C. Greenwood, R. Hinton, N. Kita, P. R. D. Mason, M. Norman, M. Ogasawara, P. M. Piccoli, D. Rhede, H. Satoh, B. Schulz-Dobrick, O. Skår, M. J. Spicuzza, K. Terada, A. Tindle, S. Togashi, T. Vennemann, Q. Xie, and Y.-F. Zheng, 2004: Further characterisation of the 91500 zircon crystal. Geostand. Geoanal. Res., 28, 9-39, doi: 10.1111/j.1751-908X.2004.tb01041.x. [Link]

Wu, S. P., M. Y. Wang, and K. J. Qi, 2007: Present situation of researches on A-type granites: A review. Acta Petrol. Mineral., 26, 57-66.

Xiao, P. X., W. F. You, C. R. Xie, P. Li, and S. M. Bai, 2011: LA-ICP-MS U-Pb detrital zircon geochronology of alumina-rich gneiss of the Helanshan complex-group in the northern segment of Helanshan Mountains and regional comparison. Geol. Bull. China, 30, 26-36.

Xu, Y. H., T. P. Zhao, P. Peng, M. G. Zhai, L. Qi, and Y. Luo, 2007: Geochemical characteristics and geological significance of the paleoproterozoic volcanic rocks from the Xiaoliangling formation in the Luliang area, Shanxi province. Acta Petrol. Sin., 23, 1123-1132.

Yan, Z., 1985: Shaanxi Granite, Xi' an Jiaotong University, Xi' an, 49, 56-57.

Yang, J. H., F. Y. Wu, X. M. Liu, and L. W. Xie, 2005: Zircon $\mathrm{U}-\mathrm{Pb}$ ages and $\mathrm{Hf}$ isotopes and their geological significance of the Miyun rapakivi granites from Beijing, China. Acta Petrol. Sin., 21, 1633-1644.

Yang, J. H., F. Y. Wu, L. W. Xie, and X. M. Liu, 2007: Petrogenesis and tectonic implications of Kuangdonggou syenites in the Liaodong Peninsula, east North China Craton: Constraints from in-situ zircon $\mathrm{U}-\mathrm{Pb}$ ages and Hf isotopes. Acta Petrol. Sin., 23, 263-276.

You, J., J. H. Luo, J. X. Cheng, S. D. Wang, H. Xu, and H. Zhao, 2014: Paleoproterozoic granite porphyry in southwestern margin of North China craton and its geological significance. Geological Journal of China Universities, 20, 368-377.

Yu, J. H., D. Z. Wang, and C. Y., Wang, 1997: Geochemical Characteristics and Petrogenesis of the Early Protero- zoic Bimodal Volcanic Rocks from Luliang Group, Shanxi Province. Acta Petrol. Sin., 13, 60-69.

Zhai, M. G. and P. Peng, 2007: Paleoproterozoic events in the North China Craton. Acta Petrol. Sin., 23, 26652682.

Zhai, M. G. and M. Santosh, 2011: The Early Precambrian odyssey of the North China Craton: A synoptic overview. Gondwana Research, 20, 6-25, doi: 10.1016/j. gr.2011.02.005. [Link]

Zhai, M. G. and M. Santosh, 2013: Metallogeny of the North China Craton: Link with secular changes in the evolving Earth. Gondwana Research, 24, 275-297, doi: 10.1016/j.gr.2013.02.007. [Link]

Zhai, M. G., B. Hu, P. Peng, and T. P. Zhao, 2014: MesoNeoproterozoic magmatic events and multi-stage rifting in the NCC. Earth Science Frontiers, 21, 100-119.

Zhang, Q., 2013: The criteria and discrimination for A-type granites: A reply to the question put forward by Wang Yang and some other persons for A-type granite: What is the essence? Acta Petrol. Mineral., 32, 267-272.

Zhang, Q., W. J. Jin, C. D. Li, and Y. L. Wang, 2010: Revisiting the new classification of granitic rocks based on whole-rock $\mathrm{Sr}$ and $\mathrm{Yb}$ contents: Index. Acta Petrol. Sin., 26, 985-1015.

Zhao, G. C., M. Sun, S. A. Wilde, and S. Z. Li, 2005: Late Archean to Paleoproterozoic evolution of the North China Craton: Key issues revisited. Precambrian Res., 136, 177-202, doi: 10.1016/j.precamres.2004.10.002. [Link]

Zhao, T. P., M. G. Zhai, B. Xia, H. M. Li, Y. X. Zhang, and Y. S. Wan, 2004: Xiong'er Group SHRIMP zircon geochronology: On the development of the North China Craton cover initial time constraints. Chin. Sci. Bull., 49, 2342-2349.

Zhao, T. P., Y. H. Xu, and M. G. Zhai, 2007: Petrogenesis and Tectonic Setting of the Paleoproterozoic Xiong'er Group in the Southern Part of the North China Craton: A review. Geological Journal of China Universities, 13, 191-206.

Zhao, T. P., X. Q. Deng, G. H. Hu, Y. Y. Zhou, P. Peng, and M. G. Zhai, 2015: The Paleoproterozoic-Mesoproterozoic boundary of the North China Craton and the related geological issues: A review. Acta Petrol. Sin., 31, 1494-1508.

Zhou, X. W., G. C. Zhao, and Y. S. Geng, 2010: Helanshan high pressure politic granulite Petrologic evidence for collision event in the western block of the North China Craton. Acta Petrol. Sin., 26, 2113-2121. 